\title{
The Implementation of Promotion through Social Media in Increasing Consumer Awareness and Purchase Intention
}

\author{
Edsa Nathasya Valentina ${ }^{1}$,Rambat Lupiyoadi ${ }^{2}$ \\ \{nathasya.edsa@gmail.com ${ }^{1}$,rambat_1@yahoo.com² \\ Universitas Indonesia ${ }^{1,2}$
}

\begin{abstract}
The purpose of this research is to focus on implementation of promotion through social media in increasing consumer awareness and purchase intention. A series of business coaching session were conducted with the owner of Lauren Collection in Tangerang, Indonesia, to see the main problem inside the MSMEs. The result from each coaching sessions were discussed and analyzed using Business Model Canvas, SWOT analysis, PESTEL analysis, Marketing mix, GAP analysis, Porter's five forces analysis and Pareto analysis. It showed that there are two main problems that need to be solved during the coaching session by managing the brand's consumer path and using social media. From the research can be found that consumer path and social media can improve consumer awareness and purchase intention
\end{abstract}

Keywords: Brand Awareness, Consumer Path, Social Media, Purchase Intention

\section{Introduction}

In recent years, MSMEs (Micro, Small and Medium Enterprises) in Indonesia have experienced a steady rapid growth. In 2012 there were only 56.5 million MSMEs in Indonesia and this number continued to grow until 2018 to 58.9 million MSMEs. The growth of MSMEs provides an important role in economic growth, therefore they must be able to keep up with the existing market development in order to survive the competition.

The current market situation is very different compared to the previous years, it can be seen from the differences in the existing behavior, opportunities and challenges. This difference occurs because of the existence of three transformative power, namely: technological development, globalization, and social responsibility [1]. The development of existing technologies, such as growth in e-commerce, internet usage and website penetration, is able to provide convenience and opportunities for the consumer to get the information as many as possible and to the company in reaching their consumer broadly. Even it says the digital revolution can change strategy in business, where consumer will become more comfortable in making purchases directly from online [1].

Research conducted in 2018 in Indonesia revealed that out of 3,012 social media users, $90 \%$ were proven to have used social media to communicate with a business and $76 \%$ acknowledged buying a product when they found the brand on social media [2]. This is in line with other research, which states that the use of social media for MSMEs is not only an effective means of communication and helps in making business decisions [3], but can also 
help in building brand awareness and creating an image for the brand [4], and encourages consumer to make purchasing decisions [5]. In the research conducted in 2017, found that interactivity, compatibility, and cost effectiveness were motivations for MSMEs in using social media to introduce their brands [6].

Lauren Collection is a footwear manufacturing SME that has been established since 2009. Initially Lauren Collection only served the manufacture of custom footwear , but in 2012 created Rewards as the brand it manages. Reward was created as a footwear product with a target market for middle-class women. Joko, as the owner of Lauren Collection, then realized that the sales will able to increase when consumer aware and know about them. Reward when selling the products from year to year only experienced increasing in sales before the national holiday month, especially between May - July . Joko hopes when consumer know about Reward as a footwear brand can encourage them to buy Reward products.

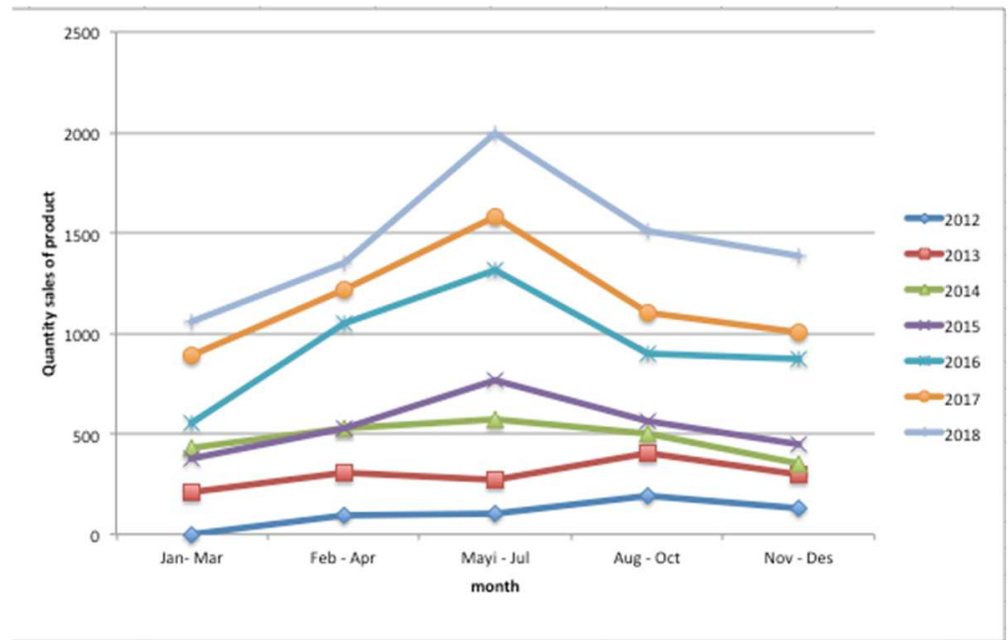

Fig 1. Reward Product Sales in 2012-2018

As explained earlier, with the development of the technology, the market condition continues to change. Today, consumer can easily find the information about brand and product just by accessing the internet from a smartphone. The ease of accessing information can encourage consumer to buy the product. Two local brands who are the competitor to Reward and has effectively using social media as their media promotion, namely, Connec and Gopro Adventure .

The two brands already have several social media which they use to build relationship with their consumer. With those accounts, it can help Connec and Gopro Adventure which are local brand in reaching consumer broadly. It is hoped that by implementing a promotion using social media can help Reward in increasing consumer awareness and purchase intention for their product. 


\section{Literature Review}

\subsection{Customer path}

With increasing consumer mobility and the development of technology, consumer often have limited time in considering a brand and become more difficult to focus on something. Therefore, company need to be able to stand out from other competitors by focusing on crucial touchpoints in building a strong relationship with consumer [7]. To be able to do this, MSMEs need to understand and create a strong customer path when buying a product.

Dereck Rucker created the consumer buying framework, there are awareness, attitude , act, and act again , known as the four A's , then as consumer get easier in getting information, the four A's framework modified into the five A's, which consists of, aware, appeal, ask, act, and advocate [7].

\subsection{Social media}

Social media, known as web 2.0 is an online form of how communication, collaboration, delivery, and cultivation between communities, individuals, and organizations that are interconnected and dependent are enhanced by technological capabilities and mobility. This media can make consumer and company more involve in receiving information about a brand. Even company can build brand awareness to influence the behavior of these consumer [4].

Those use from social media is considered to be very helpful for small company that have limited fundsto be able to reach the objectives that the company generally wants to achieve, such as: create awareness, generate interest, disseminate information, create an image, create a strong brand, stimulate trial, create buzz, gain consideration

\subsection{E-commerce}

E-commerce uses website to make transaction or facilitate the sale of a product or service online [1]. From year to year, e-commerce has experienced significant development, this is because company realize e-commerce can easily facilitate convenience, experience and information to consumer at inexpensive costs. To increase that convenience, the company need to provide a website which is fast, simple, and easy to use.

Several method that can be done by the company to encourage consumer to conduct transactions are, using high quality images, offering fast delivery, the existence of regulations regarding goods return, and the presence of online chat . Online chat is one of the most important aspects because it can help consumer to get answer from questions about the product that they want to buy quickly and accurately.

\section{Methods}

To get maximum result in the business coaching process and expected to achieve the expected goals, eight meetings were held between Lauren Collection owners and the author. In the meeting, direct and indirect qualitative data collection will be conducted. Data retrieval is done by using of depth interview with the owner and then will produce internal and external 
analysis using STP analysis, SWOT analysis, VRIO analysis, business canvas model, marketing mix, Porter's five forces analysis, GAP analysis, fishbone, and pareto analysis.

\section{Analysis}

From the two analyzes conducted, there are several things that become obstacles for Lauren Collection in increasing Reward consumer awareness and purchase intention. All analyzes are processed into GAP analysis, by comparing actual conditions and ideal rewards before doing business coaching activity. From the analysis, it can be seen that there are several GAPs that have emerged, including: (1) sales of products that have not increased, (2) not conducting marketing activities, (3) not following technological developments, (4) consumer' ignorance of Reward, and (5) have not maximized the target market. The problems that arise are then codified, namely (1) increasing the number of resellers, (2) digital promotion, and (3) identifying customer path.

Table 1. Analysis of Pareto Lauren Collection

\begin{tabular}{lllllll}
\hline No & \multicolumn{1}{c}{ GAP } & Value & Weight & $\begin{array}{l}\text { Value } \\
\text { Weight }\end{array}$ & \% & $\begin{array}{c}\text { Cumulative } \\
\%\end{array}$ \\
\hline $\mathbf{1 .}$ & $\begin{array}{l}\text { Brand awareness of } \\
\text { Reward }\end{array}$ & $\mathbf{1 0 0}$ & $\mathbf{4}$ & $\mathbf{4 0 0}$ & $\mathbf{3 9 . 4}$ & $\mathbf{3 9 . 4}$ \\
$\mathbf{2 .}$ & $\begin{array}{l}\text { Only have few } \\
\text { resellers } \\
\text { Non-routine financial }\end{array}$ & $\mathbf{9 0}$ & $\mathbf{3}$ & $\mathbf{2 7 0}$ & $\mathbf{2 6 . 6}$ & $\mathbf{6 6}$ \\
records \\
Administration \\
carried out by the \\
owner himself
\end{tabular}

From the results from the GAP analysis, it was concluded that there were several problems that arose, among others, (1) consumer brand awareness of Reward, (2) fewer resellers , (3) non-routine financial records, and (4) self-administered by the owner. These problems are then converted into Pareto diagrams, so that it appears that the main problem to solve is consumer brand awareness and a small number of resellers.

Table 2. GAP Analysis

\begin{tabular}{|c|c|c|c|c|c|c|}
\hline No. & $\begin{array}{l}\text { Variable } \\
\text { Tools }\end{array}$ & Indicator & $\begin{array}{l}\text { Actual } \\
\text { Conditions }\end{array}$ & Ideal condition & GAP & Codification \\
\hline 1 & $\begin{array}{l}\text { Business } \\
\text { process }\end{array}$ & Operation & $\begin{array}{l}\text { Product } \\
\text { manufacturing } \\
\text { has not yet } \\
\text { reached } \\
\text { production } \\
\text { capacity }\end{array}$ & $\begin{array}{l}\text { Able to maximize } \\
\text { production capacity }\end{array}$ & $\begin{array}{l}\text { Product sales } \\
\text { that have not } \\
\text { increased }\end{array}$ & $\begin{array}{l}\text { Increase the } \\
\text { number of } \\
\text { resellers }\end{array}$ \\
\hline 2 & & $\begin{array}{l}\text { Sales and } \\
\text { Marketing }\end{array}$ & $\begin{array}{l}\text { Does not have } \\
\text { a marketing }\end{array}$ & $\begin{array}{l}\text { There is a marketing } \\
\text { plan and right on }\end{array}$ & $\begin{array}{l}\text { Not conducting } \\
\text { marketing }\end{array}$ & $\begin{array}{l}\text { Digital } \\
\text { promotion }\end{array}$ \\
\hline
\end{tabular}




\begin{tabular}{|c|c|c|c|c|c|c|}
\hline & & & plan & target & activities & \\
\hline 3 & $\begin{array}{l}\text { VRIO } \\
\text { Analysis }\end{array}$ & $\begin{array}{l}\text { Intangible } \\
\text { resource }\end{array}$ & $\begin{array}{l}\text { Collaboration } \\
\text { with solid } \\
\text { suppliers }\end{array}$ & $\begin{array}{l}\text { Collaboration with } \\
\text { suppliers becoming } \\
\text { increasingly tight to } \\
\text { get competitive raw } \\
\text { materials }\end{array}$ & - & \\
\hline 4 & & & $\begin{array}{l}\text { Employees who } \\
\text { are experts in } \\
\text { their part }\end{array}$ & $\begin{array}{l}\text { Employees are not } \\
\text { only experts but are } \\
\text { also more efficient at } \\
\text { work }\end{array}$ & 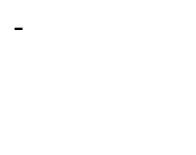 & \\
\hline 5 & $\begin{array}{l}\text { PESTEL } \\
\text { Analysis }\end{array}$ & $\begin{array}{l}\text { Technological } \\
\text { factors }\end{array}$ & $\begin{array}{l}\text { The } \\
\text { development of } \\
\text { technology has } \\
\text { changed the } \\
\text { way to do } \\
\text { marketing, but } \\
\text { has not been } \\
\text { implemented in } \\
\text { Reward }\end{array}$ & $\begin{array}{l}\text { The use of technology } \\
\text { that can help reward }\end{array}$ & $\begin{array}{l}\text { Not following } \\
\text { technological } \\
\text { development }\end{array}$ & $\begin{array}{l}\text { digital } \\
\text { promotion }\end{array}$ \\
\hline 6 & & Social culture & $\begin{array}{l}\text { The desire of } \\
\text { consumer to } \\
\text { buy footwear is } \\
\text { influenced by } \\
\text { lifestyle or } \\
\text { environmental } \\
\text { factors }\end{array}$ & $\begin{array}{l}\text { There is an increasing } \\
\text { demand from } \\
\text { consumer for existing } \\
\text { products }\end{array}$ & $\begin{array}{l}\text { Absence of } \\
\text { promotional } \\
\text { activities }\end{array}$ & $\begin{array}{l}\text { digital } \\
\text { promotion }\end{array}$ \\
\hline 7 & $\begin{array}{l}\text { SWOT } \\
\text { analysis }\end{array}$ & $\begin{array}{l}\text { Weakness } \\
\text { point }\end{array}$ & $\begin{array}{l}\text { Do not have } \\
\text { marketing } \\
\text { activities }\end{array}$ & Marketing activities & $\begin{array}{l}\text { Don't have } \\
\text { marketing } \\
\text { activities }\end{array}$ & $\begin{array}{l}\text { digital } \\
\text { promotion }\end{array}$ \\
\hline 8 & & & $\begin{array}{l}\text { Do not have an } \\
\text { offline or online } \\
\text { store that is } \\
\text { self-managed }\end{array}$ & $\begin{array}{l}\text { Has offline and online } \\
\text { stores }\end{array}$ & $\begin{array}{l}\text { Consumer } \\
\text { ignorance of } \\
\text { reward }\end{array}$ & $\begin{array}{l}\text { digital } \\
\text { promotion } \\
\text { and the } \\
\text { addition of } \\
\text { resellers }\end{array}$ \\
\hline 9 & $\begin{array}{l}\text { Fishbone } \\
\text { Diagram }\end{array}$ & Promotion & $\begin{array}{l}\text { Only use word } \\
\text { of mouth }\end{array}$ & $\begin{array}{l}\text { Marketing becomes } \\
\text { more integrated }\end{array}$ & $\begin{array}{l}\text { Only use one } \\
\text { marketing } \\
\text { activity }\end{array}$ & $\begin{array}{l}\text { Identify } \\
\text { customer } \\
\text { path }\end{array}$ \\
\hline 10 & & Product & $\begin{array}{l}\text { Because local } \\
\text { products are } \\
\text { considered not } \\
\text { to have good } \\
\text { quality and } \\
\text { models that are } \\
\text { similar to other } \\
\text { brands }\end{array}$ & $\begin{array}{l}\text { With the existence of } \\
\text { quality that is durable } \\
\text { and the innovation } \\
\text { provided can make } \\
\text { Rewards become } \\
\text { increasingly known }\end{array}$ & $\begin{array}{l}\text { Consumer } \\
\text { awareness of } \\
\text { reward is low }\end{array}$ & $\begin{array}{l}\text { Identify } \\
\text { customer } \\
\text { path }\end{array}$ \\
\hline
\end{tabular}




\begin{tabular}{|c|c|c|c|c|c|c|}
\hline 11 & & Price & $\begin{array}{l}\text { The price is not } \\
\text { much different } \\
\text { from other } \\
\text { competitors }\end{array}$ & $\begin{array}{l}\text { Able to provide } \\
\text { product value that } \\
\text { exceeds consumer } \\
\text { expectations }\end{array}$ & $\begin{array}{l}\text { Communication } \\
\text { to consumer is } \\
\text { lacking }\end{array}$ & $\begin{array}{l}\text { Identify } \\
\text { customer } \\
\text { path }\end{array}$ \\
\hline 12 & & Place & $\begin{array}{l}\text { Just use any } \\
\text { reseller }\end{array}$ & $\begin{array}{l}\text { Use of multiple sales } \\
\text { platforms }\end{array}$ & Add platform & $\begin{array}{l}\text { Spread to } \\
\text { business to } \\
\text { consumer }\end{array}$ \\
\hline 13 & $\begin{array}{l}\text { Analysis of } \\
\text { the Five } \\
\text { Forces } \\
\text { Framework }\end{array}$ & $\begin{array}{l}\text { bargaining } \\
\text { power of } \\
\text { buyers }\end{array}$ & $\begin{array}{l}\text { The price } \\
\text { offered cannot } \\
\text { be too high }\end{array}$ & $\begin{array}{l}\text { Prices offered are not } \\
\text { much different from } \\
\text { competitor but can } \\
\text { provide more value }\end{array}$ & $\begin{array}{l}\text { Consumer do } \\
\text { not know the } \\
\text { value of } \\
\text { Reward }\end{array}$ & $\begin{array}{l}\text { digital } \\
\text { promotion }\end{array}$ \\
\hline 14 & & $\begin{array}{l}\text { threat of } \\
\text { substitute of } \\
\text { products or } \\
\text { services }\end{array}$ & $\begin{array}{l}\text { The products } \\
\text { offered are only } \\
\text { two types, } \\
\text { namely casual } \\
\text { sandals and } \\
\text { mountain } \\
\text { sandals }\end{array}$ & $\begin{array}{l}\text { Can provide other } \\
\text { product variant again }\end{array}$ & $\begin{array}{l}\text { Not yet } \\
\text { maximizing the } \\
\text { market }\end{array}$ & $\begin{array}{l}\text { digital } \\
\text { promotion }\end{array}$ \\
\hline
\end{tabular}

Both of these problems are expected to be done by using strategies that are processed using TOWS analysis. The analysis will then use the strengths and opportunities that already discussed with the owner, which will be able to help Reward to solve the above problems, by carrying out activities as follows:

1. Evaluate Reward logo

2. Identify costumer path in buying Reward's product

3. Choose promotional media that are in accordance with Reward's target market

4. Determining price arrangement that can attract potential resellers

Table 3. TOWS Analysis of Lauren Collection

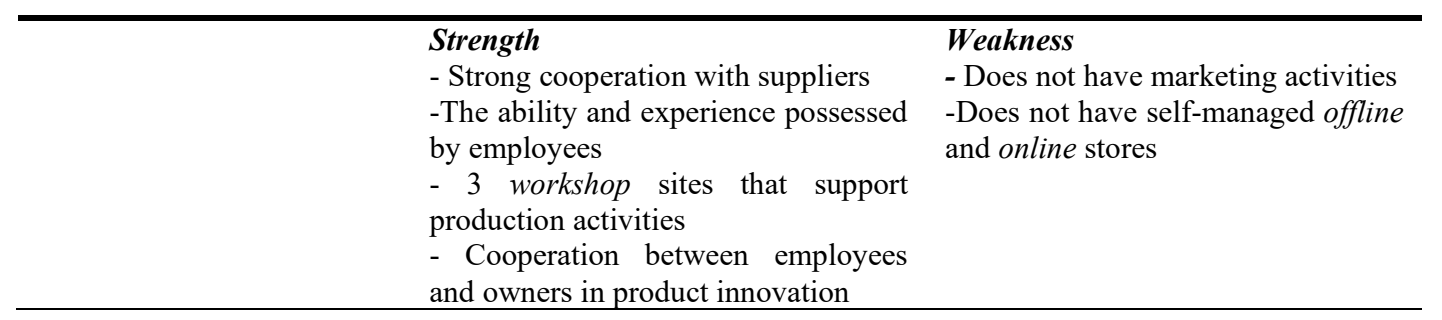




\begin{tabular}{|c|c|c|}
\hline $\begin{array}{l}\text { Opportunities } \\
\text {-Search potential resellers } \\
\text { - There is an opportunity to } \\
\text { promote through social } \\
\text { media and e-commerce to } \\
\text { reach a wider target market. }\end{array}$ & $\begin{array}{l}\text { SO strategy } \\
\text {-Promotion carried out in accordance } \\
\text { with a predetermined target market. }\end{array}$ & $\begin{array}{l}\text { WO Strategy } \\
\text {-Identify customer path } \\
\text { - Reward brand management so that } \\
\text { it matches the target market } \\
\text {-The use of promotional media is } \\
\text { right to be able to build } \\
\text { communication from consumer }\end{array}$ \\
\hline $\begin{array}{l}\text { Threats } \\
\text {-Consumer who are } \\
\text { sensitive to selling prices } \\
\text { - Local competitors offering } \\
\text { similar products }\end{array}$ & $\begin{array}{l}\text { ST strategy } \\
\text { - Establish cooperation with suppliers } \\
\text { so as to reduce the price of production }\end{array}$ & $\begin{array}{l}\text { WT Strategy } \\
\text {-Additional resellers }\end{array}$ \\
\hline
\end{tabular}

\section{Discussion}

The logo can add personality to the brand and promote it and involve the relationship with consumer [8]. With the development of technology, making logos has also undergone significant changes, many company have modified their logos to be simpler, brighter, more modern, so they can be used on many platforms [9].

Before changing the logo into the new one, there were a survey to 30 people who have qualification as Reward's target market. From the survey, it showed that 27 people agreed the old logo did not show as a brand for woman, they said the old logo are too macho, too masculine, and the color are too bright. So, in order to that, after the discussion there are some changes such as the shape of letters using Baloo letters, where the shape of the letters means carefree, confident, and entertaining and uses red and black colors in accordance with the colors of the existing logos to make it easier for consumer to remember the new Reward logo, where red according to research is often associated with excitement and passion, and black is related to elegance and sophistication, the nature is in line with the target market of Reward, middle-class women with ages $18-34$ years.

\section{$\frac{\Delta}{\text { RFWAID }}$ \\ RE W $\angle \mathbf{R} \mathbf{D}$ \\ Fig 2. Before and After Reward Logo}

After making changes to the Reward logo, the next activity is the stage in making Reward promotional media. The 3 stages previously explained are (1) determining touchpoints and channels in the customer path, (2) identifying the most important touchpoints and channels, and (3) fixing and integrating predetermined important points [7]. 

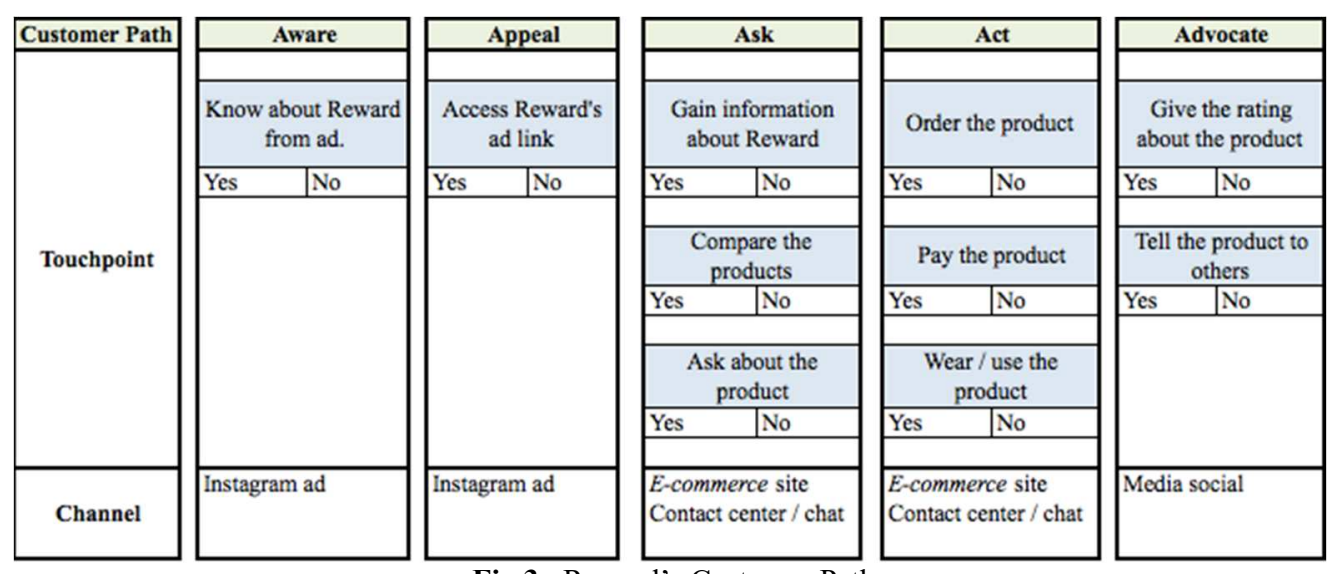

Fig 3. Reward's Customer Path

For identifying the touchpoints, Reward did an observation to the competitor. From that, it can be seen Reward need a seamless path for their consumer to make an enjoyable process to them, and as of now, many companies using digital promotion media to create that. Social media especially Instagram is used more by women 18-29 years old who are the same target market as Reward [4]. Even 36\% of MSMEs in Indonesia that have gone online using Instagram as a social media in introducing their products [24].

The use of customer path is then processed into promotional media by paying attention to the following elements:

\section{High-quality visuals}

The quality of the images given is very important to be able to stand out and attract attention. This photo taking is done using a mini photo studio. By using this photo studio, it is expected that it will be easily understood by admin rewards when taking photos for upcoming products. In addition, after taking photos, training was also conducted on how to edit these photos so that they were more interesting.

\section{A compelling caption}

Selection of words must contain an invitation to see the products offered voluntarily. In Instagram, because the target market is women with an age range of 18-34 years old, then in some pictures the caption will be given using English, with the aim of being a universal language.

\section{Relevant hashtags}

With the hashtags make Reward content easier to find, so you can add new followers. The use of hashtags is adjusted to the Reward profile , it is decided to use hashtags , including: \#rewardfootwear, \#sandal, \#sandalgunung, \#sandalwanita, \#madeinIndonesia..

\section{Community engagement}

This is done by giving questions on the content provided and installing the Instagram story that can be easily seen by followers of the Rewards account and other accounts. In the content, a link can also be installed that will be connected directly to other Reward 
promotional media, so that it will be easier for them when they want to find out more about Reward products.

5. Follow recommended specs and dimensions

In installing effective content on Instagram, Reward need to pay attention to the conditions that have been given, so that when the content has been installed, it will not cause problems or attract attention from other accounts. Content that complies with these provisions will make it easier for consumer to view the contents of the Reward account. In this element, Rewards will install content with a predetermined size of 1080 px x 1080 px or video range with a maximum of 15 seconds playback.

The use of promotional media through Instagram then encourage consumer to be able to find out about Reward's products, that can be seen from profile accounts that visit Reward's shopee account and Instagram account.

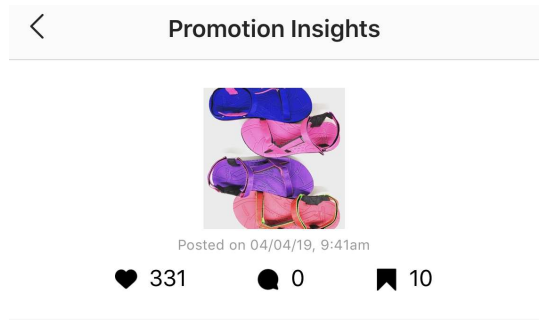

Interactions

0

Visit Website

$0 \%$ from promotion

Visit Profile

$97 \%$ from promotion

Email

$100 \%$ from promotion

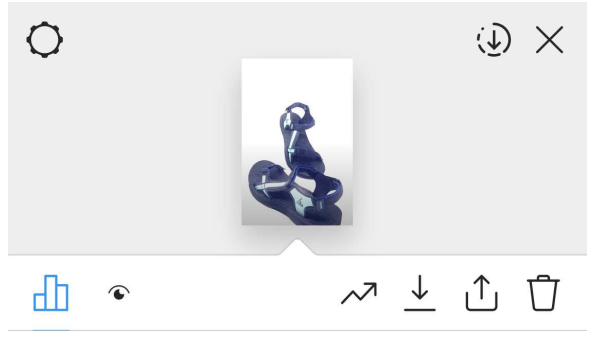

Interactions

$$
72
$$

79

Visit Profile

$47 \%$ from promotion
129

Visit Website

91\% from promotion

Promotion Clicks

225

Fig 4. Results of promotion through Instagram

The promotion then pushes those Instagram account to visit Reward's Shopee account. After continuous promotion through Instagram and Shopee, starting from Instagram content to Instagram story, consumer who like Reward product are increasing in the period of February May 2019. This is in accordance with the results of previous studies that say that social media can help MSMEs in build consumer awareness and become an effective communication [3]. 
Table 4. Number of Consumer Rewards

\begin{tabular}{lcc}
\hline \multicolumn{1}{c}{ Month } & \multicolumn{2}{c}{ Number of consumer } \\
& Like Reward products & Buy Rewards products \\
\hline February & 2 & 1 \\
2019 & & \\
March 2019 & 31 & 15 \\
April 2019 & 55 & 49 \\
May 2019 & 69 & 115 \\
\hline
\end{tabular}

\section{Conclusion}

Logo is one of the elements that can help company to distinguish their brands from other competitors. In addition, logos can also increase consumer awareness of rewards, therefore it is decided that changes to the old Reward logo are needed. These changes aim to make the new logo easier to remember, simple and relevant.

The logo is then used in the Reward consumer flow plan and adjusted to the touchpoints that have been determined together with the owner. The media used to be able to realize touchpoints consists of Instagram and Shopee, the use of these two media is based on the target market who are familiar with the use of these technologies. To be able to attract attention, then learning techniques of product photo taking, understanding of Instagram starting from installing content to advertising, and how to be able to serve consumer to finally have the desire to buy Reward products. The results of this activity can be seen from the increasing number of accounts that see and follow Instagram Reward accounts and want to open a shopee account and find information about Rewards by asking questions and answers about products with the admin.

The activity of determining touchpoints and the media used to support each stage of the consumer flow, helps reward to increase awareness of Instagram account users on product rewards and the number of followers of reward intagram accounts. This is in line with previous research, where the use of social media for MSMEs can build consumer awareness [4] and become an effective means of communication [3]. The media also encouraged consumer to make purchasing decisions by convincing them at the ask and act stage in the Reward consumer flow, in accordance with the research conducted in 2015 [5].

The limited time for this research can be an opportunity for follow-up that can be done by Reward and other students in conducting business coaching activities, among others: using a celebrity endorsement that is in line with the target market Reward on social media, adding e-commerce media so that can reach consumer more widely, and improve relationship management with existing and future resellers .

\section{Reference}

[1] K. L. K. Philip Kotler, by Philip Kotler (Author), Kevin Lane Keller. Essex: Pearson Education Limited., 2016.

[2] S. Kurniawan, "Instagram makin populer di kalangan umkm,” 2018. [Online]. Available: https://marketeers.com/instagram-makin-populer-di-kalangan-umkm/.

[3] S. Priambada, "Manfaat penggunaan media sosial pada usaha kecil menengah ( UKM ) ( The 
benefit of Social Media for Small Medium Enterprises )," Semin. Nas. Sist. Inf. Indones., 2015

[4] M. A. B. George E. Belch, George Edward Belch, Advertising and Promotion: An Integrated Marketing Communications Perspective. New York: McGraw-Hill Education, 2014.

[5] S. Hassan, S. Z. A. Nadzim, and N. Shiratuddin, "Strategic Use of Social Media for Small Business Based on the AIDA Model," Procedia - Soc. Behav. Sci., 2015, doi: 10.1016/j.sbspro.2015.01.363.

[6] R. Odoom, T. Anning-Dorson, and G. Acheampong, "Antecedents of social media usage and performance benefits in small- and medium-sized enterprises (SMEs)," J. Enterp. Inf. Manag., 2017, doi: 10.1108/JEIM-04-2016-0088.

[7] P. Kotler, H. Kartajaya, and I. Setiawan, Marketing 4.0: Moving from Traditional to Digital. 2017.

[8] P. Kotler, G. Armstrong, L. C. Harris, and N. Piercy, Principles of Marketing European Edition. 2005.

[9] D. Airey, Logo Design Love: A Guide to Creating Iconic Brand Identities. Adams Media (, 2010.

[10] (2018). Perkembangan UMKM di Tanah Air. Profit. (Website broadcast). Jakarta: CNBC Indonesia 
